\title{
The Academic Librarian and Faculty Status in the 1980s: A Survey of the Literature
}

Kee DeBoer and Wendy Culotta

The status of librarians has changed over the past several years and continues to change. The authors have created a composite profile of the current academic librarian based on a survey of the library literature of the 1980s. Specific topics considered were faculty versus academic status, criteria used for evaluation, tenure, support for research, sabbaticals and released time, pressure for publishing, and productivity in publishing. Librarians' attitudes toward faculty status at the present time were considered, as were some questions about the future.

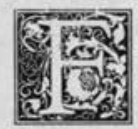

aculty status for academic librarians continues to be a hot topic. Much has been written about it during the past twentyfive years. After years of discussion, ACRL adopted Standards for Faculty Status for College and University Librarians in 1971, but that did not end the discussion. Articles continue to appear in the professional literature on all sides of the issue. But just where do we stand at the present time? Are we truly faculty members? Do we have tenure? Who evaluates us? What criteria are used in the evaluations? Is there pressure to publish? How much publishing have we been doing? Where do we publish? Do we get the time and financial support needed for our research? Is it all worth the benefits we receive as faculty members?

The ideal way to find answers to such questions would be to conduct a survey of all the academic librarians in the country. The magnitude of such an undertaking is too overwhelming to contemplate. Instead, the authors reviewed the professional literature to find surveys published in the 1980s. The data compiled in those more limited studies were merged to develop a composite picture of the general situation. This is not a scientific study with a carefully balanced sampling of all types of libraries. In fact, it is somewhat weighted in favor of ARL libraries, because more studies have been made of those libraries than of any other group. Small, academic libraries are probably underrepresented. In spite of the limitations, a profile drawn from the professional literature should prove useful. If we can determine our present status with its advantages and disadvantages, we can better know where we want to go in the future.

In order to make the composite picture as up-to-date as possible, the authors considered only articles written in the 1980 s, although much of the literature published prior to 1980 is still relevant. Background reading for the earlier period can be found by consulting Virgil Massman's excellent book Faculty Status for Librarians. ${ }^{1}$ Bibliographies contained in articles written by Fred Batt ${ }^{2}$ and Gaby Divay ${ }^{3}$ cover the literature of the interim period from Massman's book (1972) until 1980.

Because of the numerous referrals to the authors of the various studies included in this survey, the authors found it less cumbersome and repetitious to refer only to the first author of each article. Exceptions

Kee DeBoer was Coordinator of Reference and Wendy Culotta is Online Coordinator at the California State University, Long Beach, California, 90840. 
have been made when there are two articles by the same author. Readers should examine the references for complete information about authorship of the articles.

\section{TERMINOLOGY}

One of the most striking impressions of the review relating to faculty status for librarians in the 1980s is the great variation among responses. Part of the reason for the divergence lies in the differences in interpretation of terms. Some writers separated faculty status from academic status, and some did not. There was also confusion in the minds of some librarians who answered the questionnaires. They did not always know what benefits were available to them. In some cases, librarians in the same institution gave very different answers to the same questions.

What is faculty status? What is academic status? Some people use the terms interchangeably, but to others there are distinct differences. Sewell differentiated between the two terms. "With faculty status, or full faculty status as it is sometimes referred to, librarians accept all the rules, regulations, procedures and benefits of the teaching faculty in a strict sense. ... With academic status, librarians enjoy some but not all of the privileges of the teaching faculty but do not hold rank." ${ }^{\prime 4}$

Faculty status as defined by ACRL's Standards for Faculty Status for College and University Librarians (quoted in part) would include the following: ${ }^{5}$

1. Each librarian should be assigned general responsibilities within his particular area of competence. He should have maximum possible latitude in fulfilling these responsibilities.

2. College and university libraries should adopt an academic form of governance.

3. Librarians should be eligible for membership in the academic senate or equivalent body at their college or university on the same basis as other faculty.

4. The salary scale for librarians should be the same as that for other academic categories with equivalent education and experience.
5. Librarians should be covered by tenure provisions the same as those of other faculty.

6. Librarians should be promoted through ranks and steps on the basis of their academic proficiency and professional effectiveness. A peer review system similar to that used by other faculty is the primary basis of judgment in the promotion process for academic librarians.

7. Sabbatical and other research leaves should be available to librarians on the same basis, and with the same requirements, as they are to other faculty.

8. Librarians should have access to funding for research projects on the same basis as other faculty.

9. Librarians in colleges and universities must have the protection of academic freedom.

Several, but not all, of the criteria will be considered. Only information available in the literature was included, and some areas have not been reported in the surveys of library situations.

\section{FACULTY STATUS}

John DePew's comment that "almost $79 \%$ of the academic libraries now have some sort of faculty status ${ }^{\prime \prime 6}$ is often cited. Tassin found that $80 \%$ of the librarians in his survey of 35 state universities in the southwestern United States had faculty status or equivalency. ${ }^{7}$ In a survey of 188 college and university libraries in New York State, Benedict reported that most or all librarians in $72 \%$ of the responding libraries had faculty status. ${ }^{8}$ Fred Hill surveyed 51 librarians picked at random from The American Libraries Directory and found that $61 \%$ claimed to have faculty status.'

More than half ( 25 of 44 ) of the libraries in Greg Byerly's survey of Ohio colleges and universities reported faculty status. When the author analyzed the benefits available at each institution, however, he found that only 11 of the schools actually provided librarians with all of the benefits of teaching faculty; the others gave "most of the benefits." 10

The Academic Status Survey published by College $\&$ Research Libraries News reported that $44 \%$ of the libraries surveyed 
by ACRL claimed to have full faculty status for librarians. ${ }^{11}$ The breakdown by category was:

ARL libraries $30 \%$

University libraries $34 \%$

Four-year college libraries

Two-year college libraries

$26 \%$

$72 \%$

Payne's survey of 49 non-ARL libraries showed 59 with full faculty status. ${ }^{12}$ W. Bede Mitchell surveyed 138 directors of CRL libraries and reported that $36 \%$ had faculty status for librarians equivalent to that of teaching faculty. However, when private institutions were separated from public universities, the figures were quite different: $88 \%$ of the public institutions and only $12 \%$ of the private schools granted librarians faculty status. ${ }^{13}$

Three separate studies reported on faculty status in various schools that are members of ARL. The figures reported were:

$\begin{array}{lcll} & \begin{array}{c}\text { All } \\ \text { Schools }\end{array} & \text { Public } & \text { Private } \\ \text { Rayman }^{14} & 35 \% & & \\ \text { Horn }^{15} & 48 \% & 64 \% & 20 \% \\ \text { English }^{16} & 46 \% & 61.4 \% & 18.7 \%\end{array}$

\section{TENURE}

There was not so much disparity between the figures reported by various authors on the topic of tenure as there was on faculty status. The percentage of universities granting tenure to librarians ranged from $42.7 \%$ to $61 \%$ :

\section{All}

Schools Public Private

\begin{tabular}{|c|c|}
\hline ARL (English) ${ }^{17}$ & $42.7 \%$ \\
\hline $\begin{array}{l}\text { New Jersey (Reel- } \\
\text { ing) }\end{array}$ & $48 \%$ \\
\hline Ohio (Byerly) ${ }^{19}$ & 48 \\
\hline ARL (Rayman) ${ }^{20}$ & $57 \%$ \\
\hline $\begin{array}{l}\text { New York (Bene- } \\
\text { dict) }\end{array}$ & \\
\hline CRL (Mitchell) & $\%$ \\
\hline Non-ARL (Payne) & \\
\hline
\end{tabular}

\section{EVALUATION}

Two major articles about peer evaluation of librarians (Judy Horn and Karen Smith and Gemma DeVinney) were both based on surveys of librarians at ARL libraries. Smith and DeVinney stated that
$94 \%$ of the librarians answering their survey (530 librarians in large academic libraries) had peer review of some sort that culminated in a decision by the library director. Review committees at 14 of the libraries used faculty-wide committees while 17 relied on committees composed of library peers. ${ }^{24}$

Horn agreed that peer review has become the norm. Sixty-seven percent of the librarians in her sample have peer review. Twenty-six of the 36 responding libraries use committees composed of librarians for the review; the others use a faculty committee. In addition to a review by a committee of peers, librarians are also evaluated by administrators (supervisors, department heads, deans, vice chancellors, provosts). ${ }^{25}$

Librarians in $93 \%$ of the Rocky Mountain survey had the opportunity for peer review for tenure, ${ }^{26} 63 \%$ of the New Jersey sample, ${ }^{27}$ and $46 \%$ of the New York librarians. ${ }^{28}$ At the low end of the range are Nancy Emmicks's study reporting 33\% with peer review ${ }^{29}$ and the Ohio study, which found that only $23 \%$ of the libraries provided that opportunity. ${ }^{30}$

\section{CRITERIA USED FOR EVALUATION}

Only in the Rocky Mountain area were the majority of librarians ( $70 \%$ ) judged on the same tenure criteria as are the teaching faculty, and even in that group there were dramatic differences. In New Mexico, $87 \%$ of the librarians reported identical tenure requirements, while only $8 \%$ of the $\mathrm{Ar}$ izona librarians reported that the same criteria were used for librarians and for the teaching faculty. ${ }^{31}$ The other studies reported that criteria for librarians were different from those of teaching faculty, or if the same standards were used, were modified to reflect the unique role of librarians. $^{32,33,34,35}$

Job performance is still the top priority in librarian evaluation according to Emmick $^{36}$ and Karen Smith and Tamara Frost. ${ }^{37}$ Several authors saw research and publication as increasingly important criteria for evaluation but not so important as other aspects of the job. Smith and Frost's 
study of 33 ARL libraries ranked publications as the second most important criterion, ${ }^{38}$ while Emmick's paper surveying 367 U.S. and Canadian libraries ranks research/publication fifth after job performance, supervisory evaluation, active professional membership, and continuing education. ${ }^{39}$ Although publication was encouraged for promotion and tenure in many libraries, few universities actually required librarians to publish according to Ronald Rayman ${ }^{40}$ and Joyce Payne, ${ }^{41}$ but Mitchell found that $46.9 \%$ of the libraries queried required evidence of publication. ${ }^{42}$

The importance of research and publication is shown in Mitchell's study of tenure approval rates over a five-year period in 38 universities. Of the 329 librarians applying for tenure during that time period, 61 or $18.5 \%$ were denied tenure. Thirty-five of the 61 denials were based on an inadequate record of research and publication and 21 for inadequate job performance. ${ }^{43}$

\section{SUPPORT FOR \\ RESEARCH ACTIVITIES}

An almost universal complaint of librarians is lack of time for research. Payne contends that "Time is the one resource usually not available to librarians. ${ }^{\prime 44}$ Every study that addressed work schedules reported that most librarians work thirtyfive to forty hours a week, twelve months a year.

Released time for professional development was available in many libraries but was sometimes to be used only for committee work and conferences. ${ }^{45,46}$ In the New York study, $67 \%$ of the librarians were eligible for released time for professional duties, but only $20 \%$ could get it for research. ${ }^{47}$ In the ARL studies, Rayman found that librarians in $51 \%$ of his sample had research time available, ${ }^{48}$ while Payne reported $46 \% .{ }^{49}$ Reeling reported that $90 \%$ of the librarians in the New Jersey group were eligible for released time for professional activity, ${ }^{50}$ but there was no indication if that included time for research.

Emmick studied the amount of time available to librarians for professional development. After studying 367 libraries, she concluded that most libraries grant somewhere between $1 \%$ and $5 \%$ of a librarian's time for all forms of professional development. ${ }^{51}$ That equates to twentyfour minutes to two hours a week.

Nine- or ten-month appointments are available at a small number of libraries. The option was available in $6.1 \%$ of Payne's non-ARL libraries, ${ }^{52}$ in $6.7 \%$ of the Ohio group, $16 \%$ of the New York libraries, $18 \%$ of Reeling's New Jersey survey, ${ }_{56}^{55}$ and $25 \%$ of English's ARL universities.

\section{SABBATICALS}

Librarians in the Rocky Mountain region reported the highest figure in the category of sabbaticals. Other surveys reported that librarians were eligible for sabbaticals in the following percentages of the samples:

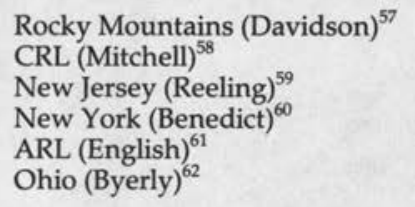

$85 \%$ $76.3 \%$ $70 \%$ $64 \%$ $50 \%$ $49 \%$

Funding for research was available to the majority of librarians in the composite sample, more often from the university rather than from the library. Reeling found that only $40 \%$ of the New Jersey libraries surveyed made research funds available, ${ }^{63}$ but higher figures were reported in other surveys:

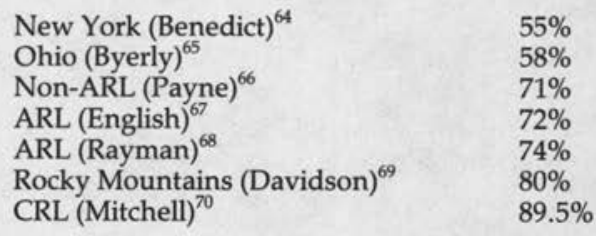

Travel funds may be even more readily available. Both Byerly and English reported that all of the universities that make travel money available to teaching faculty also make it available to librarians. $^{71,7}$

\section{PRODUCTIVITY IN PUBLISHING}

Although emphasis on publishing and the number of articles by academic librarians have both increased in recent years, ${ }^{73}$ output by individual librarians remains 
low. In John Olsgaard's study of librarians whom he considered to be successful, the career publication rate was 1.5 publications per librarian ( 2.0 publications for each man; 1.1 for each woman). ${ }^{74}$ Smith and Frost found that half of the librarians in their sample had not published at the time they received tenure, ${ }^{75}$ but, in some cases, tenure was awarded several years earlier, and the situation in the 1980 s may be different. Payne found that approximately $25 \%$ of academic librarians were engaged in some sort of publication activity.

When comparing pre- and post-tenure rates of publication, Paula Watson ${ }^{\pi}$ and Smith and Frost ${ }^{78}$ failed to find any significant difference in the rate of publication. Sylvia Krausse traced patterns of publication by academic librarians in 12 general academic library journals over a ten-year period. With a range of 1 to 14 , the mean number of articles per librarian was 1.4 articles in the ten-year period. ${ }^{79}$ Seventyeight percent of the librarians represented had one publication in that time span. Those librarians may have also published books or articles in journals not reviewed by the study, so these figures do not necessarily provide a complete picture.

Two studies were made using similar methodology but using different lists of journals. John and Jane Olsgaard reviewed authorship in 5 general library journals. Martha Adamson followed the same model but chose specialized library journals. The findings were similar in the two studies: proportionately, women librarians publish less than do men in the library field. While $94 \%$ of academic librarians are women, only $61.5 \%$ of the articles analyzed by Olsgaard and Olsgaard were published by women. Men, who make up $16 \%$ of the profession, published $38.5 \%$ of the articles. ${ }^{80}$ Adamson found a slightly higher rate for women: $43.7 \%$ women, $56.3 \%$ men. $^{81}$

Krausse found that librarians at large libraries publish more than do librarians at smaller institutions. More than half of the articles surveyed were written by librarians working in libraries with holdings of one million volumes or more. ${ }^{82}$ Krausse hypothesizes that the greater productivity of librarians in large libraries may be explained by the availability of more extensive research resources and also because librarians often have a narrower range of responsibilities than do librarians in smaller institutions.

\section{FAVORED JOURNALS FOR PUBLICATIONS}

Payne contends that the form of publication is less significant than is the fact of publication. ${ }^{83}$ Although in the past preferential treatment was given to publication in the field of librarianship, that has changed. At the present time, publications in the library field and those in subject disciplines are equally acceptable, according to Priscilla Geahigan ${ }^{84}$ and Payne. ${ }^{.5}$ Rayman found that 2 libraries in his sample required publication to be in the library field, while 8 had no such requirement. ${ }^{86}$ Mitchell presented comparative statistics on the acceptability of various types of publications within the library/information science field and those outside it. Most of the surveyed libraries gave credit for books, chapters in books, articles in refereed or nonrefereed journals, conference papers, and book reviews, whether or not the subject matter was library related. Almost every library $(97.4 \%)$ gave credit for articles in refereed journals in the area of library/information science, while $89.5 \%$ gave credit for such publications in other fields. For articles in nonrefereed journals, the figures were $89.5 \%$ for library-related materials, $68.4 \%$ for other areas."

Krausse examined more than 4,000 articles published in 12 general academic journals to see which journals were preferred by academic librarian authors. The favored journals were College $\&$ Research Libraries, Journal of Academic Librarianship, Library Resources \& Technical Services, and $R Q{ }^{88}$ Nearly $30 \%$ of all publications by academic librarians appeared in College $\mathcal{E} R e$ search Libraries or Journal of Academic Librarianship. $^{89}$

\section{ATTITUDE TOWARD FACULTY STATUS}

Faculty status continues to be controversial. In Batt's opinion, faculty status for li- 
brarians can be more of a liability than a help. ${ }^{90}$ Some librarians feel that although they have increasingly taken on the responsibilities that accompany faculty status, they have not received the full benefits of it. Russ Davidson ${ }^{91}$ and DePew ${ }^{92}$ reported some dissatisfaction with the responsibilities and requirements that accompany faculty status. English ${ }^{93}$ and $\mathrm{Hill}^{\mathrm{s}}$ both suggested the possibility that the trend toward faculty status for librarians has peaked and has started to fall back slightly. Some libraries are looking for alternatives. ${ }^{95}$

In contrast to the articles discussing problems and doubts about faculty status, Robert Sewell's article recounts a success story. The University of Illinois at Urbana has instituted complete faculty status with positive results. Sewell's assessment: " $\mathrm{Li}$ brarians involved in their university community, research and professional activities, are better able to confront their library work than those who remain insulated within their own libraries. The benefits of faculty status accrue not only to individual librarians, but also to their libraries and universities." had similar experiences but have not yet reported them in the professional literature of the 1980s.

\section{PROFILE}

What conclusions can be drawn from this mass of information and statistics? What characteristics does the typical librarian in the 1980s have? According to the literature reviewed, the typical librarian would

- have some type of faculty or academic status, but perhaps not full faculty status;

- have tenure if employed at a state university, but not if at a private school;

- almost certainly be evaluated by peers;

- be encouraged to publish, but would not be required to do so;

- be evaluated on job performance above all other criteria;

- work thirty-five to forty hours a week, twelve months a year;

- have little released time, probably none for research;

- have published approximately one ar- ticle (slightly more if a man) in either College \& Research Libraries or Journal of Academic Librarianship; and

- be having a few doubts that faculty status is the best alternative for librarians.

The profile gives us some indication of where we are now. Librarians continue to move toward faculty status but are still in a period of transition. In many universities, librarians are being asked to add research and publication to their already busy schedules, but, in many cases, the libraries are not able to provide them with the time and support they need.

\section{THE FUTURE?}

Where do we go from here? At the present time it is difficult to determine if full faculty status is the best system available because it has not been tested adequately with all of its benefits and all of its responsibilities. The University of Illinois at Urbana has reported good results in its implementation of faculty status for librarians, but can the experience of one library be generalized to other institutions?

There are still questions to be answered. If librarians are to be evaluated on the same basis as are teaching faculty, we need to know more about what will be expected of us. Will doctorates or second master's degrees be required? How much publication is required for tenure and promotion? Can present attention to library service ideals be maintained if librarians focus more directly on their own research projects?

It would be helpful to have more studies of the experiences in various universities as more of us move toward faculty status. Mitchell's study listed reasons for rejections of tenure applications in ARL schools. ${ }^{97}$ Additional studies on that topic would be helpful, as well as studies on such topics as pre- versus post-tenure productivity, comparisons of schedules of teaching faculty and library faculty, scheduling problems resulting from flexible work hours, and other related subjects.

Since January 1, 1985, the California State University system, consisting of nineteen campuses, has had a collective bargaining agreement with its faculty, in- 
cluding librarians. Tenure, peer review, sabbaticals, and travel funds are available to all faculty, and all are on the same salary schedule. It is too early for an analysis of this development, but in a few years it will be interesting to see whether all faculty are evaluated on the same criteria or if adjustments are made to allow for differences in job responsibility.

Further reports on faculty status, both positive and negative, would be useful to librarians across the country. Academic librarians are continuing to search for the system that will function most effectively in individual libraries. We can profit from the experiences of our colleagues.

\section{REFERENCES}

1. Virgil F. Massman, Faculty Status for Librarians (Metuchen, N.J.: Scarecrow, 1972).

2. Fred Batt, "Faculty Status for Academic Librarians: Justified or Just a Farce?" in Issues in Academic Librarianship: Views and Case Studies for the 1980s and 1900s, ed. Peter Spyers-Duran and Thomas W. Mann, Jr. (Westport, Conn.: Greenwood, 1985), p.115-28.

3. Gaby Divay and Carol Steer, "Academic Librarians Can Be Caught by the Pressure to Do Research," Canadian Library Journal 40:91-95 (Apr. 1983).

4. Robert G. Sewell, "Faculty Status and Librarians: The Rationale and the Case of Illinois," College \& Research Libraries 44:212-22 (May 1983).

5. Association of College and Research Libraries, "Standards for Faculty Status for College and University Librarians," College \& Research Libraries News 33:210-12 (Sept. 1972).

6. John N. DePew, "The ACRL Standards for Faculty Status: Panacea or Placebo?" College \& Research Libraries 44:407-13 (Nov. 1983).

7. Anthony G. Tassin, "Faculty Status for Librarians: Progress and Perplex," LLA Bulletin 47:83-86 (Fall 1984).

8. Marjorie A. Benedict, Jacquelyn A. Gavaryck, and Hanan C. Selvin, "Status of Academic Librarians in New York State," College \& Research Libraries 44:12-19 (Jan. 1983).

9. Fred E. Hill and Robert Hauptman, "A New Perspective on Faculty Status," College \& Research Libraries 47:156-59 (Mar. 1986).

10. Greg Byerly, "The Faculty Status of Academic Libraries in Ohio," College \& Research Libraries 41:422-29 (Sept. 1980).

11. "Academic Status Survey," College \& Research Libraries News $12: 171$ (June 1981).

12. Joyce Payne and Janet Wagner, "Librarians, Publication, and Tenure," College \& Research Libraries 45:133-39 (Mar. 1984).

13. W. Bede Mitchell and L. Stanislave Swieszkowski, "Publication Requirements and Tenure Approval Rates: An Issue for Academic Librarians," College \& Research Libraries 46:249-55 (May 1985).

14. Ronald Rayman and Frank William Goudy, "Research and Publication Requirements in University Libraries," College \& Research Libraries 41:43-48 (Jan. 1980).

15. Judy Horn, "Peer Review for Librarians and Its Applications in ARL Libraries," in Academic Libraries: Myths and Realities (Chicago: Assn. of College and Research Libraries, 1984), p.125-40.

16. Thomas G. English, "Librarian Status in the Eighty-Nine U.S. Academic Institutions of the Association of Research Libraries: 1982," College \& Research Libraries 44:199-211 (May 1983).

17. Ibid., p. 204.

18. Patricia Reeling and Beryl K. Smith, "Faculty Status: A Realistic Survey," New Jersey Libraries 16:17-25 (Fall 1983).

19. Byerly, "The Faculty Status of Academic Librarians in Ohio," p.425.

20. Rayman and Goudy, "Research and Publication Requirements," p.45.

21. Benedict, Gavaryck, and Selvin, "Status of Academic Librarians," p.16.

22. Mitchell and Swieszkowski, "Publication Requirements," p.251.

23. Payne and Wagner, "Librarians, Publication, and Tenure," p.134.

24. Karen F. Smith and Gemma DeVinney, "Peer Review for Academic Librarians," Journal of Academic Librarianship 10:87-91 (May 1984).

25. Horn, "Peer Review for Librarians," p.138.

26. Russ Davidson, Connie Capers Thorson, and Diane Stine, "Faculty Status for Librarians: Querying the Troops," College \& Research Libraries 44:414-20 (Nov. 1983).

27. Reeling and Smith, "Faculty Status: A Realistic Survey," p.21.

28. Benedict, Gavaryck, and Selvin, "Status of Academic Librarians," p.16. 
29. Nancy J. Emmick, "Release Time for Professional Development: How Much for Research?" in Academic Libraries: Myths and Realities (Chicago: Assn. of College \& Research Libraries, 1984), p.124-34. 30. Byerly, "The Faculty Status of Academic Librarians in Ohio," p.424.

31. Davidson, Thorson, and Stine, "Faculty Status for Librarians," p.418.

32. Byerly, "The Faculty Status of Academic Librarians in Ohio," p.425.

33. English, "Librarian Status," p.204.

34. Horn, "Peer Review for Librarians," p.136.

35. Payne and Wagner, "Librarians, Publication, and Tenure," p.137.

36. Emmick, "Release Time for Professional Development," p.131.

37. Karen F. Smith, Tamara U. Frost, Amy Lyons, and Mary Reichel, "Tenured Librarians in Large University Libraries," College \& Research Libraries 45:91-98 (Mar. 1984).

38. Ibid., p.97.

39. Emmick, "Release Time for Professional Development," p.131.

40. Rayman and Goudy, "Research and Publication Requirements," p.45.

41. Payne and Wagner, "Librarians, Publication, and Tenure," p.137.

42. Mitchell and Swieszkowski, "Publication Requirements," p.252.

43. Ibid.

44. Payne and Wagner, "Librarians, Publication, and Tenure," p.139.

45. Davidson, Thorson, and Stine, "Faculty Status for Librarians," p.417.

46. Emmick, "Research Time for Professional Development," p.131.

47. Benedict, Gavaryck, and Selvin, "Status of Academic Librarians," p.16.

48. Rayman and Goudy, "Research and Publication Requirements," p.45.

49. Payne and Wagner, "Librarians, Publication, and Tenure," p.134.

50. Reeling and Smith, "Faculty Status: A Realistic Survey," p.21.

51. Emmick, "Release Time for Professional Development," p.131.

52. Payne and Wagner, "Librarians, Publication, and Tenure," p.137.

53. Byerly, "The Faculty Status of Academic Librarians in Ohio," p.425.

54. Benedict, Gavaryck, and Selvin, "Status of Academic Librarians," p.16.

55. Reeling and Smith, "Faculty Status: A Realistic Survey," p.21.

56. English, "Librarian Status," p.204.

57. Davidson, Thorson, and Stine, "Faculty Status for Librarians," p.419.

58. Mitchell and Swieszkowski, "Publication Requirements," p.253.

59. Reeling and Smith, "Faculty Status: A Realistic Survey," p.21.

60. Benedict, Gavaryck, and Selvin, "Status of Academic Librarians," p.16.

61. English, "Librarian Status," p.204.

62. Byerly, "The Faculty Status of Academic Librarians in Ohio," p.426.

63. Reeling and Smith, "Faculty Status: A Realistic Survey," p.21.

64. Benedict, Gavaryck, and Selvin, "Status of Academic Librarians," p.16.

65. Byerly, "The Faculty Status of Academic Librarians in Ohio," p.426.

66. Payne and Wagner, "Librarians, Publication, and Tenure," p.136.

67. English, "Librarian Status," p.204.

68. Rayman and Goudy, "Research and Publication Requirements," p.45.

69. Davidson, Thorson, and Stine, "Faculty Status for Librarians," p.419.

70. Mitchell and Swieszkowski, "Publication Requirements," p.253.

71. Byerly, "The Faculty Status of Academic Librarians in Ohio," p.426.

72. English, "Librarian Status," p.21.

73. Sylvia C. Krausse and Janice F. Sieburth, "Patterns of Authorship in Library Journals by Academic Librarians," Serials Librarian 9:127-38 (Spring 1985).

74. John N. Olsgaard, "Characteristics of 'Success' among Academic Librarians," College \& Research Libraries 45:5-14 (Jan. 1984).

75. Smith, Frost, Lyons, and Reichel, "Tenured Librarians," p. 96.

76. Payne and Wagner, "Librarians, Publication, and Tenure," p.138.

77. Paula D. Watson, "Production of Scholarly Articles by Academic Librarians and Library School Faculty," College \& Research Libraries 46:334-42 (July 1985).

78. Smith, Frost, Lyons, and Reichel, "Tenured Librarians," p.96.

79. Krausse and Sieburth, "Patterns of Authorship," p.137.

80. John N. Olsgaard and Jane Kinch Olsgaard, "Authorship in Five Library Periodicals," College \& Research Libraries 41:49-53 (Jan. 1980).

81. Martha C. Adamson and Gloria J. Zamora, "Publishing in Library Science Journals: A Test of the 
Olsgaard Profile," College \& Research Libraries 42:235-41 (May 1981).

82. Krausse and Sieburth, "Patterns of Authorship," p.132.

83. Payne and Wagner, "Librarians, Publication, and Tenure," p.138.

84. Priscilla Geahigan, Harriet Nelson, Stewart Saunders, and Lawrence Woods, "Acceptability of Non-Library/Information Science Publications in the Promotion and Tenure of Academic Librarians," College \& Research Libraries 42:571-75 (Nov. 1981).

85. Payne and Wagner, "Librarians, Publication, and Tenure," p.138.

86. Rayman and Goudy, "Research and Publication Requirements," p.45.

87. Mitchell and Swieszkowski, "Publication Requirements," p.252-53.

88. Krausse and Sieburth, "Patterns of Authorship," p.134-35.

89. Ibid., p. 134 .

90. Batt, "Faculty Status for Academic Librarians: Justified or Just a Farce?," p.115.

91. Davidson, Thorson, and Stine, "Faculty Status for Academic Librarians," p.419.

92. DePew, "The ACRL Standards for Faculty Status," p.407-13.

93. English, "Librarian Status," p.205.

94. Hill and Hauptman, "A New Perspective on Faculty Status," p.157.

95. Joan M. Bechtel, "Academic Professional Status: An Alternative for Librarians," Journal of Academic Librarianship 11:289-92 (Nov. 1985).

96. Sewell, "Faculty Status and Librarians," p.221.

97. Mitchell and Swieszkowski, "Publication Requirements," p.252. 